by Jose Luis Sanchez-Cortez*, Daniel Jaque-Bonilla, Marco Simbaña-Tasiguano,

Diana Astudillo-Bravo, and Estefania Cabascango-Chiliquinga

\title{
Participatory strategies applied for the geoconservation of speleological heritage at the Napo Sumaco Geopark (Ecuador)
}

Universidad de Guayaquil, Guayaquil, Ecuador; Amazonian Regional University Ikiam, Tena, Ecuador; Napo Sumaco Geopark Foundation, Tena, Ecuador; *Corresponding author, E-mail: jose.sanchezco@ug.edu.ec

(Received: May 8, 2021; Revised accepted: January 9, 2022)

https://doi.org/10.18814/epiiugs/2022/022001

Napo Sumaco Geopark is located in the Amazonian province of Napo, northeastern Ecuador. It covers an approximate area of $1,780 \mathrm{~km}^{2}$, and 68,000 inhabitants, living in approximately 70 local communities, that identify themselves as Amazonian kichwas. The main geological interests in this area, are linked to Cretaceous sedimentary basins, volcanic processes and quaternary deformation structures, as well as a vast territory with karstic characteristics. During the systematic process of caves inventory, applying participant observation methods, some improper and inappropriate conditions and attitudes were observed in the community management of speleological resources. Due to the unsuitable situations and actions observed inside the caves, some measures were proposed which contribute to the improvement of this problem. Thus, using participatory processes, some key ideas could be generated to improve the management and handling of the speleological elements of the territory. In conjunction with collaborating institutions and local governments, frequently develops workshops and training aimed at the awareness and conservation of geological heritage sites. In addition, owners of sites of interest receive workshops on the use of exploration equipment, rope progression and underground cartography. Finally, the contribution of the Napo Sumaco Geopark in cave conservation is considered within the management plans and master plan.

\section{Introduction}

Ecuadorian Amazon is recognized worldwide for its great biodiversity, in addition its historical and cultural richness from the Amazonian indigenous peoples settled in the region (Toulkeridis et al., 2015). The settled communities that living in the upper Amazon River Basin are identified as Kichwas and are divided in various communities in the Upper Amazon River Basin (Arias-Gutierrez et al., 2016). Napo Sumaco Geopark is located in the province of Napo, and its main interest, refer to its abundant biological diversity and endemic fauna
(Arias et al., 2012), resulting from the native tropical humid forests and stable climatic conditions (Finer et al., 2008). Also worth highlight, in this framework, some geological features of considerable academic, cultural and social interest (Sanchez-Cortez, 2017). These include the intrusions of Jurassic granite in the north-western sector of the province of Napo, which coincides with the formation of the Guacamayos Mountains and the foot of the Andean Mountain, Colonso and the Llanganates Mountains (Fig. 1) (Baldock, 1982; Balseca et al., 1993). Further to the east, is possible to find rock masses formed by volcanic lava (176 million years ago) and compacted sediments dating from 110 to 25 million years. In the eastern sector of the province, appear a great diversity of karst landscapes, resulting from weathering and erosion of limestones rocks present in the Napo formation (Upper Cretaceous). These geological features and associated reliefs are bounded by the Napo River to the south, and it spreads to the north towards the border with Colombia (Constantine et al., 2018).

The limestones rocks of the Napo formation date from 90 to 70 million years (Baldock, 1982), due to its percentage of calcium carbon, in addition to being in a tropical region with abundant precipitation and large amounts of organic matter, these rocks present dissolution processes, which for thousands of years have given rise to endocarstic (caves and caverns) and exocarstic (lapiaz, towers and canyons) structures (Figs. 2 and 3) (Sanchez-Cortez, 2017).

Lithology within the Napo Sumaco Geopark, allow evidence of processes of paleogeographic changes after the Upper Cretaceous. So, Tena (Upper Cretaceous - Paleocene), Tiyuyacu (Paleocene - Eocene), Chalcana (Oligocene - Miocene) and Arajuno (Miocene) formations, show a transition sequence of sedimentary deposits from marine to continental facies (Baby et al., 2014). In addition, in this territory can observe reverse fault structures, as a product of displacements towards the west, product of the continental drift of the South American Plate and diastrophism. In this area, to the north of the Napo Sumaco Geopark, is located part of the Napo Uplift (Pliocene), one of the most important geological structures in the territory. This uplift is a positive dome structure, approximately $10,000 \mathrm{~km}^{2}$ in area, and slopes of approximately $1.6 \mathrm{~km}$ (Balseca et al., 1993). Napo Uplift is responsible of the presence of Quaternary sub-andean volcanism. Sumaco volcano (Fig. 4) and its extruded materials, correspond to typologies outside of the Andean context, their main products being alkaline basalt (basanite) 


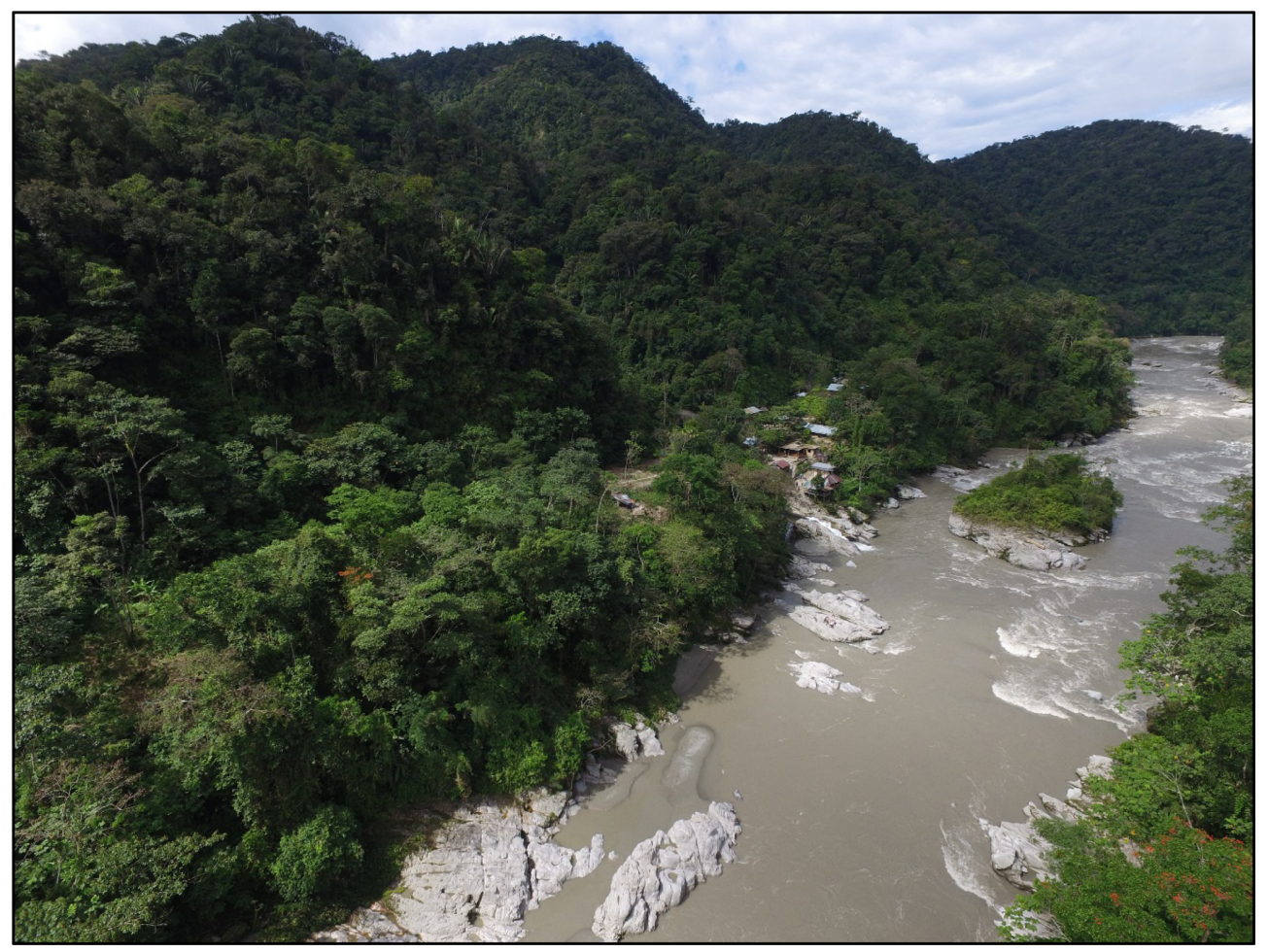

Figure 1. Aerial view from Laguna Azul Geosite and Jatun Yaku River. It is in the kichwa community of Alukus, south of the Napo Sumaco Geopark. The main attraction of this geosite lies in the formation of cavities due to water erosion in the granite batholith of Abitagua (Middle Jurassic).

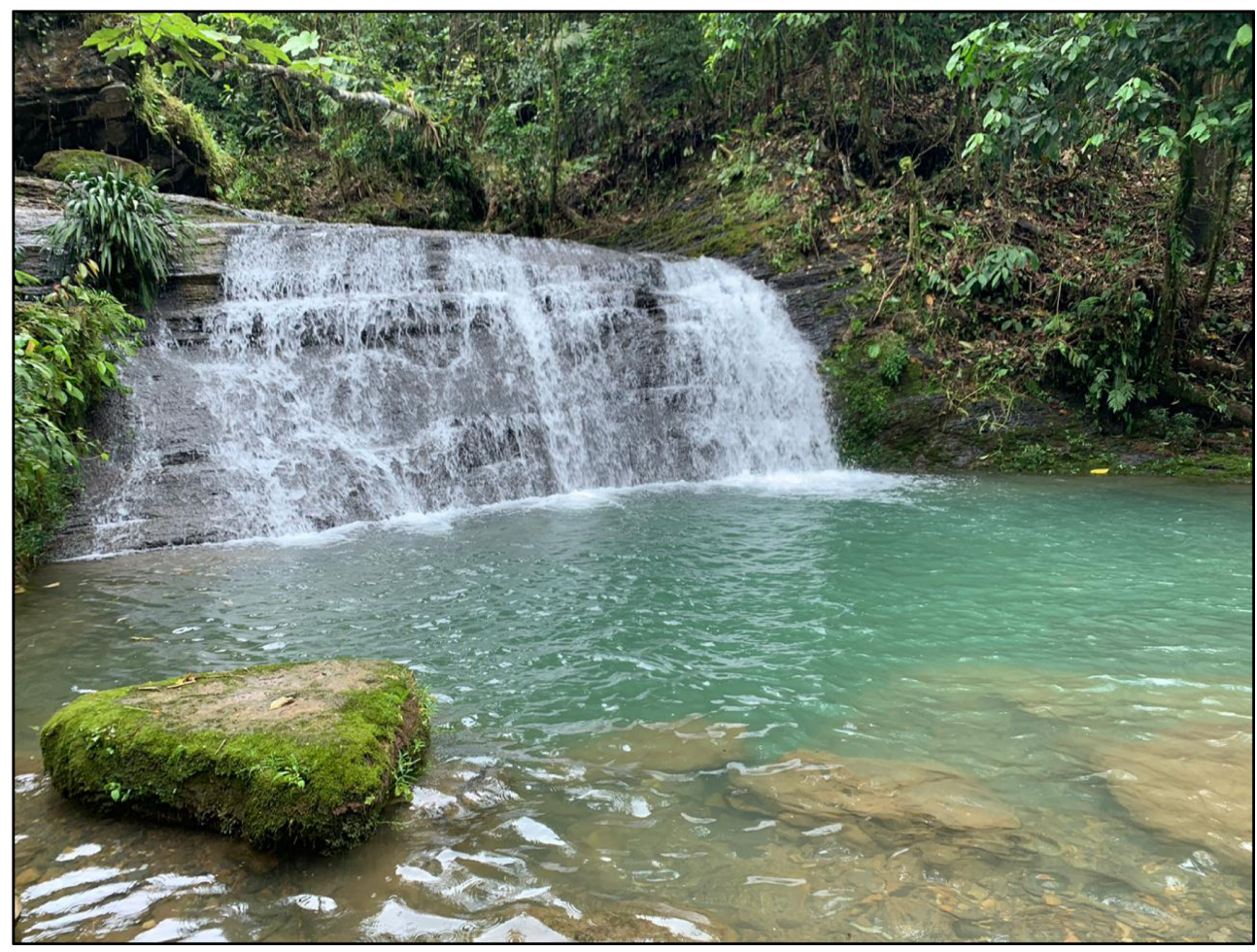

Figure 2. "Canta Gallo" waterfall. Located in the Napo karst relief, Rumiñahui community, near the "Churo" Geosite. It is found in shales and limestones of the Napo formation (Upper Cretaceous).

and phonolites (Barragan and Baby, 2004).

All these geological characteristics and geological elements present in this territory, have an important link with knowledge and citizen science. Local cultures give meanings to their geographic elements, as part of their culture and customs (Sánchez-Cortez, 2017). In such virtue, the present work seeks to define a link and enhance dialogue of 


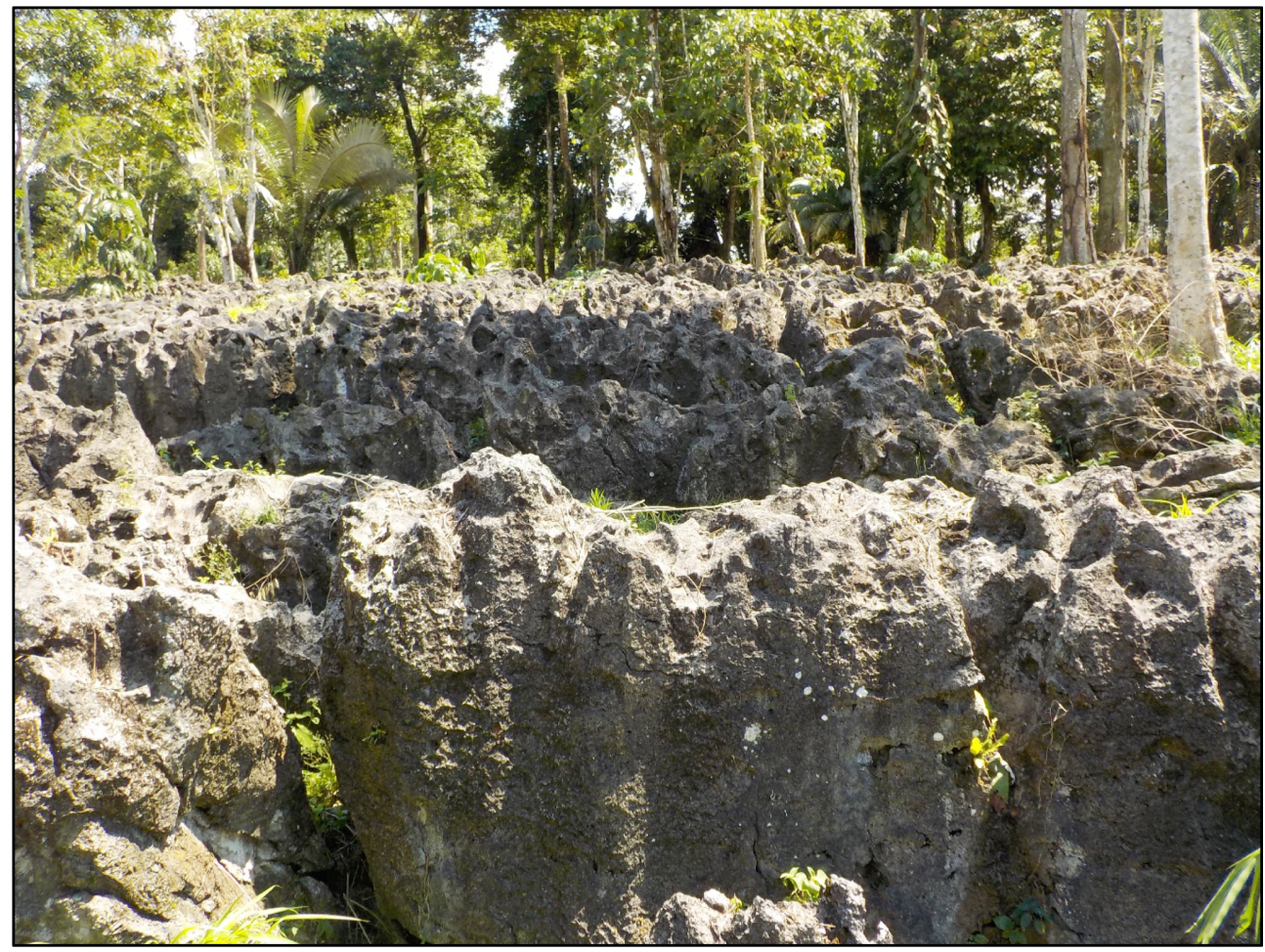

Figure 3. Geosite Labyrinths of the Napo River. Outcrop of exokarstic relief type lapiaz, south of the Napo Sumaco Geopark, located in the Napo formation (Upper Cretaceous). In the figure you can see details of bio karstic weathering.

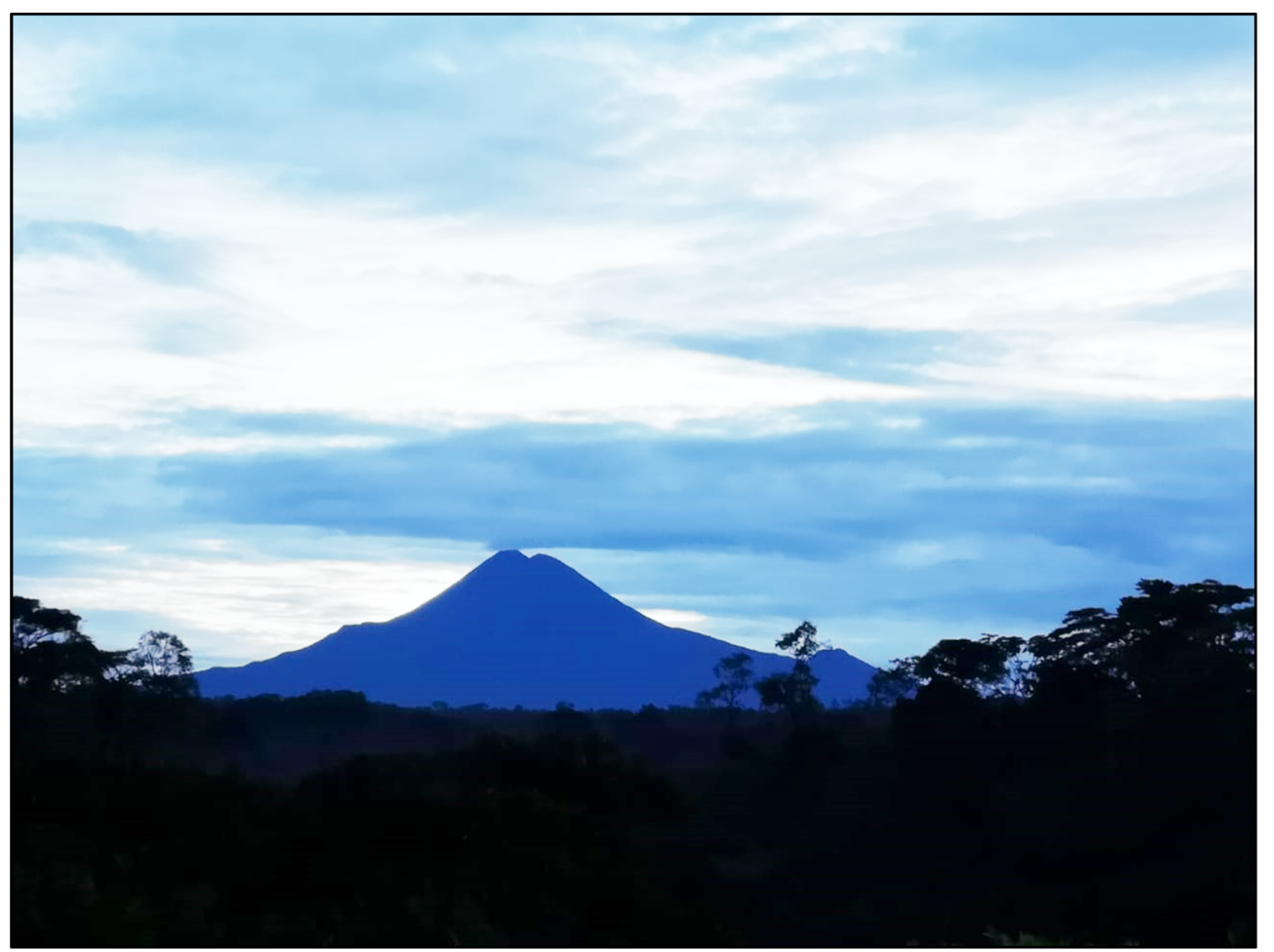

Figure 4. Sumaco Volcano (3800). This active stratovolcano represents the highest point of the Napo Sumaco Geopark. Sumaco is one of the best references of quaternary volcanism in the Ecuadorian sub-Andean zone. Being located at the eastern end of the sub-Andean zone, this volcano presents an important ecosystem and climatic variability unique to the region.

knowledge between Earth Sciences (from speleological aspect) and local knowledge, uses and customs, in order to understand and strengthen the dynamics between science and community within the Napo Sumaco
Geopark. Literature normally addresses one problem or the other, in individually. It is no common in the scientific system to generate strong rapprochements between normal science and citizen science (Peters 
and Besley, 2019; Trojan et al., 2019), therefore, this work will contribute positively to this problem.

In this geological context, historically Kichwa Amazonian peoples have been associated with caves and caverns. Oral history, beliefs, myths and legends make reference to diverse beings from the underworld that inhabit the interior of the caves and where only the yachak (shaman) has access, as such traditional knowledge and spiritual practices are closely linked to these caves. Entering and leaving a cave denotes a process of spiritual rebirth. They are also considered as places of refuge for various animals and people. During the Spanish conquest, these caves served as strategic points for the advancement of the Amazon warriors (Sánchez-Cortez, 2017). This geological element can create a reconstruction of the local cosmovision, being a tool for the transmission of oral traditions between one generation and another, but this relationship has been seldom studied (Zurita-Benavides, 2014; Palacios-Villavicencio, 2015; Sanchez-Cortez et al., 2017). As such, the caves also serve as elements of social and economic dynamics within the rural communities that house them, and therefore man has a close relationship with these spaces from various perspectives (Manzanilla, 1994; Sanchez-Cortez and Ortega, 2015). These social and cultural dynamics can be so close and interesting that often geological interest is left aside.

Since ancient times, the various uses given to caves and their surroundings have been recorded by different cultures as places of worship, burials and shelter. Here, we find cave paintings depicting the physiological characteristics of these inhabited spaces and of the socio-spatial organization of the daily life of the first societies. Places such as these are considered one of the most ancient expressions of human civilizations. Napo Sumaco UNESCO Aspiring Geopark is a territory formed through the interaction between the strength and the spiritual beliefs of its peoples and the eco geological landscape that they have occupied since time untold (Lino, 2001; Descola, 2004; Toledo et al., 2008).

\section{Naporuna World View and the Underworld}

Naporuna cosmovision is vitalist, animist and is impregnated with the life of the ayllu, as an integrating factor of the economic, political, social, religious activities and their relations with the world of the invisible lives (supaykuna) of the forces of nature (ushaykuna) and the world of the ancestors (ñawpakuna). They conceive the world from his vision of "complementary opposites", from where the dimension we inhabit (kunan pacha or current dimension) is given a polarity of spaces and times, in which supaykuna and ushaykuna are integrated into a third dimension or kay pacha, the space of the human, governed by the force, spirit of life or runa samay. Similarly it has a dual geographical conception of the world: janan (above) ukupacha (below) (Goldaraz, 2005).

This correlation between space and time is presented in relation to the caves and the geological formations of which they are a part. Ukupacha, is the world where the caves are located, is part of every system of knowledge, enriched from the Amazonian Kichwa world view and related to diverse natural elements such as the rivers. In the Kichwa worldview, caves, besides being a geological and geomorphological element, represent the entrance to the other world, to the spiritual world; therefore, it is common before entering the cave, request permission from the spirits that inhabit them (Fig. 5).

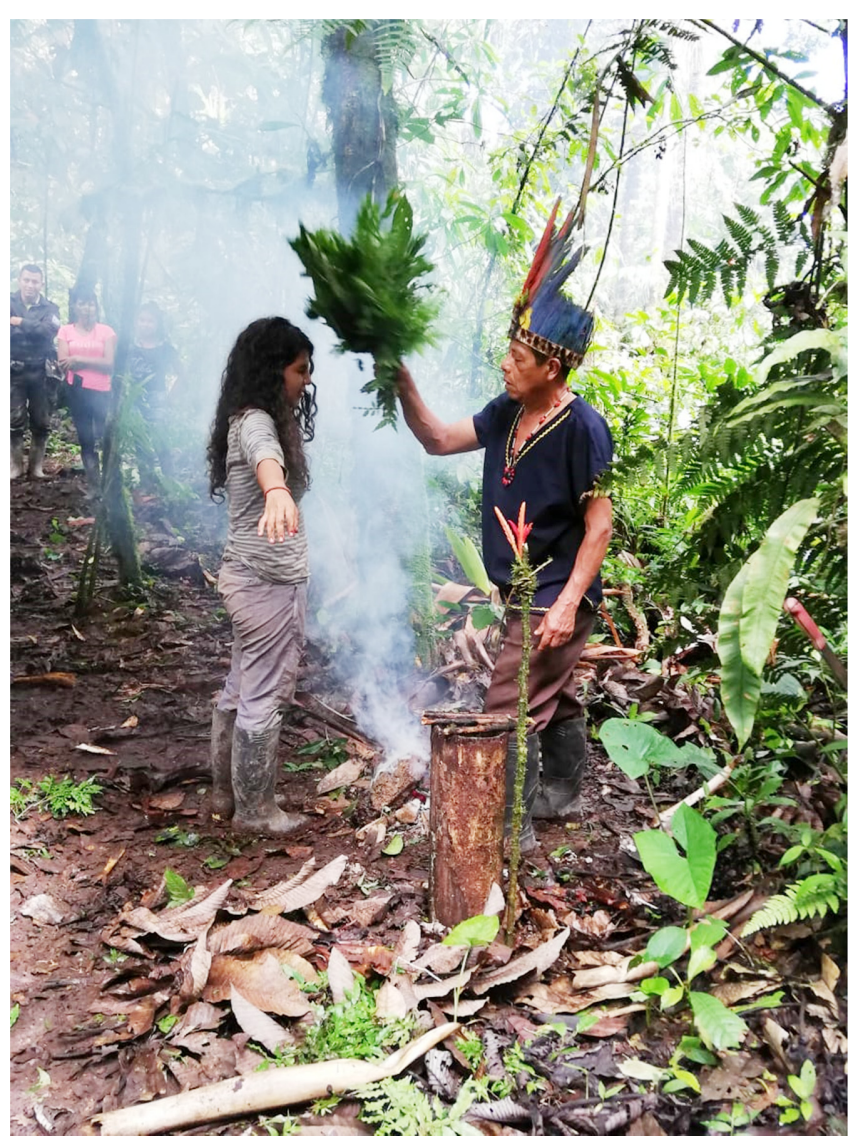

Figure 5. Shamanic ritual of "La limpia". Before entering the karst systems in the Kichwa territory, the yachak realize a cleansing and purification ritual, which includes requesting permission from the spirits for to can entry to the caves.

The mountains also connected geological formations with the people, such as the volcanoes, with an important spiritual background, related to the formation and preparation to be a yachak and other levels of wisdom (Grefa, 2020). For example, Sumaco volcano $(3,800$ m.a.s.l.), has witnessed stories that detail the presence of sorcerers; indeed, Ordoñez de Cevallos (1691), recounts his surprising experience, when on his ascent to the Sumaco volcano, he met an indigenous Cofán sorcerer in the crater of the volcano, who according to account that he had arrived there to be able to speak with "the devil".

Ukupacha, where the Supay or Nugui inhabit and is described as a subway world with its social organization, where the human being of the kay pacha is related in a mystical way with these spirits from the samay or vital force, is a dimension where the time passes very fast (Andy et al., 2012). Oral history, beliefs, myths and legends refer to the spiritual power that lives inside the caves and caverns (for example Lagarto, El Duende, Jumandy, Uctu Iji Changa caves), which in ancient times, only the Yachak had access to, and gives an account of the historical relationship that the Kichwa Amazonian people of the Upper Napo have had with them.

Entering and leaving a cave denotes a process of spiritual rebirth, they are also considered places of refuge for various animals and people, and oral Kichwa narrative also refers to the time of the Spanish conquest where these caves (Jumandy Caves) were strategic points for advancement of the Amazon warriors (Sanchez-Cortez, 2017). 
Furthermore, given the importance of this geological element for the local world view, it can be a tool to transmit oral traditions from one generation to another (Zurita-Benavides, 2014; Palacios-Villavicencio, 2015; Sanchez-Cortez et al., 2017).

Caves also serve as elements of social and economic dynamics within the rural communities where they are located, and therefore man has a close relationship with these spaces from various perspectives (Manzanilla, 1994; Sanchez-Cortez and Ortega, 2015).

\section{Tourism and sustainable use}

Tourism is one of the main activities for the social and economic use of caves, and has represented a focal point for the increase of visitors to sites of geological importance in various countries (Wimbledon and Smith-Meyer, 2012). The different uses of the underground water resources present in the caves (thermal water, energy, medicine, water with soluble minerals and others), have an infinity of uses with great economic significance (Langer, 2020).

Geotourism is a viable alternative for the use of geological and geographic resources, as a means of using and generating enjoyment from geosystems in a sustainable manner (Gray, 2011). The geotourism approach involves the conservation of geological elements of global importance, while also raising awareness of terrestrial dynamics through outdoor activities, museums and visitor centers. These activities are aimed at audiences of different ages (Newsome et al., 2012).

Within this framework, geotourism is a form of tourism that is fully compatible with geoparks (Ólafsdóttir and Dowling, 2014), since geoparks promote the sustainable use of territories with geological heritage and their unique features that represent the interaction of the various actors in mutual and beneficial relationships, embodied in living and active landscapes (Farsani et al., 2010; UNESCO, 2015). In other words, natural cavities are resources with a diverse number of uses. Currently, several caves have come to be considered as tourist attractions, as a result of the work done by the kichwa communities, which has worked since the 1980s, adapting the concepts of ecotourism and geotourism for the development of community tourism networks (Vasquez Vega, 2015). Biogeologically, caves represent expressions of life, interrelation, memories of past events as a testimony of movements, flows and interactions (Ramos Donato, 2019) and therefore interdisciplinarity is a fundamental part of working in and studying such places.

During the construction of the Speleological Guide of Napo (Sánchez-Cortez, 2017) and through tourist, academic, and educational visits to the caves, within the territory of Napo Sumaco Geopark, it has been identified that there is a need to improve management norms within these territories. Many of the guides of the province are agile and know the territory, and is fundamental that include in their work security norms, for themselves and for protection of the geological heritage inside the caves. The lack of adequate equipment and the manip-

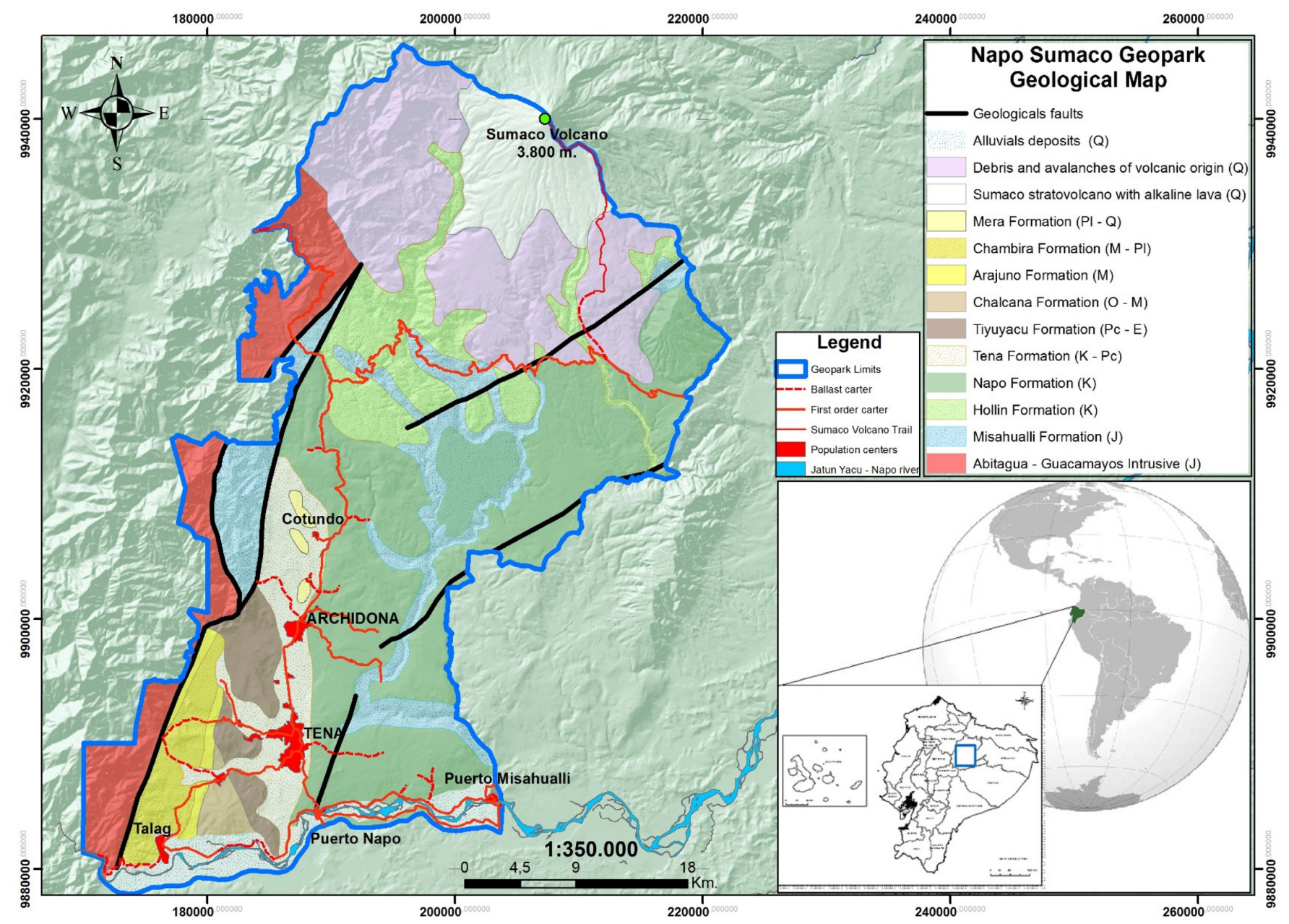

Figure 6. Geological map of the Napo Sumaco Geopark. This map shows the entire stratigraphic sequence and the main geological structures. 
ulation of the speleothems represent the most frequent inappropriate behaviors in speleology (Palmer, 2012; Bartholeyns, 2016). In this paper, strategies applied by the Napo Sumaco Geopark are analyzed to complement the knowledge of local guides and to improve the experience of tourists in the caves of this territory.

\section{Methodology}

\section{Study Area: Napo Sumaco Geopark}

Napo Sumaco Geopark covers an area of $1,780 \mathrm{~km}^{2}$ and extends to the south-central region of the Napo Province. The geomorphological and physiographic patterns of the area are determined by an altitudinal gradient, which allows the differentiation of different climatic floors that has given the characteristic biological and hydrologic diversity of the Amazon basin. In this territory, Cretaceous rocks of the eastern Ecuadorian Basin emerge. This section consists of the Hollín (Lower Cretaceous), Napo (Upper Cretaceous) and Tena (Upper Cretaceous - lower Paleocene) formations, and to the west, overlay paleogenic and neogenic formations of continental origin (Yuquilema, 2010; Baby et al., 2014). In this territory the fluvio-quaternary reliefs prevail, as well as the karst reliefs developed on the Napo formation (Fig. 6).

\section{Methodological Approach}

The present work is based on an inventory of natural cavities reported by inhabitants of the territory, through the geotouristic inventory of natural cavities in the province of Napo, which was developed in order to develop a database of caves used for tourist activities in the province of Napo. 35 cavities were inventoried, 34 of which are within Napo Sumaco Geopark (Fig. 7). Based on the information obtained in the inventory of caves, additional information was collected about the current conditions of use and management of the caves in Napo Sumaco Geopark. This database is a tool for management and decision-making within the territory, regarding conservation.

In addition, parallel processes of interaction with the owners and tourist guides of the caves were applied, to appreciate technical organization, attitudes and behaviors of the local guides inside the caves during the tourist tours. Were applied qualitative research methods, such as direct and participant observation (deductive method), as they allowed for a first-hand experience of the interactions between the relevant actors and the geological heritage (Taylor and Bogdan, 1986).

Observations of the inventoried cavities and qualitative assessments were established empirically, following a Likert scale based on the percentages of occurrence of each parameter. This scale stipulates values between 81 and 100 correspond to very high occurrences; between 61 and 80 , high occurrences; between 41 and 60 mean occur-

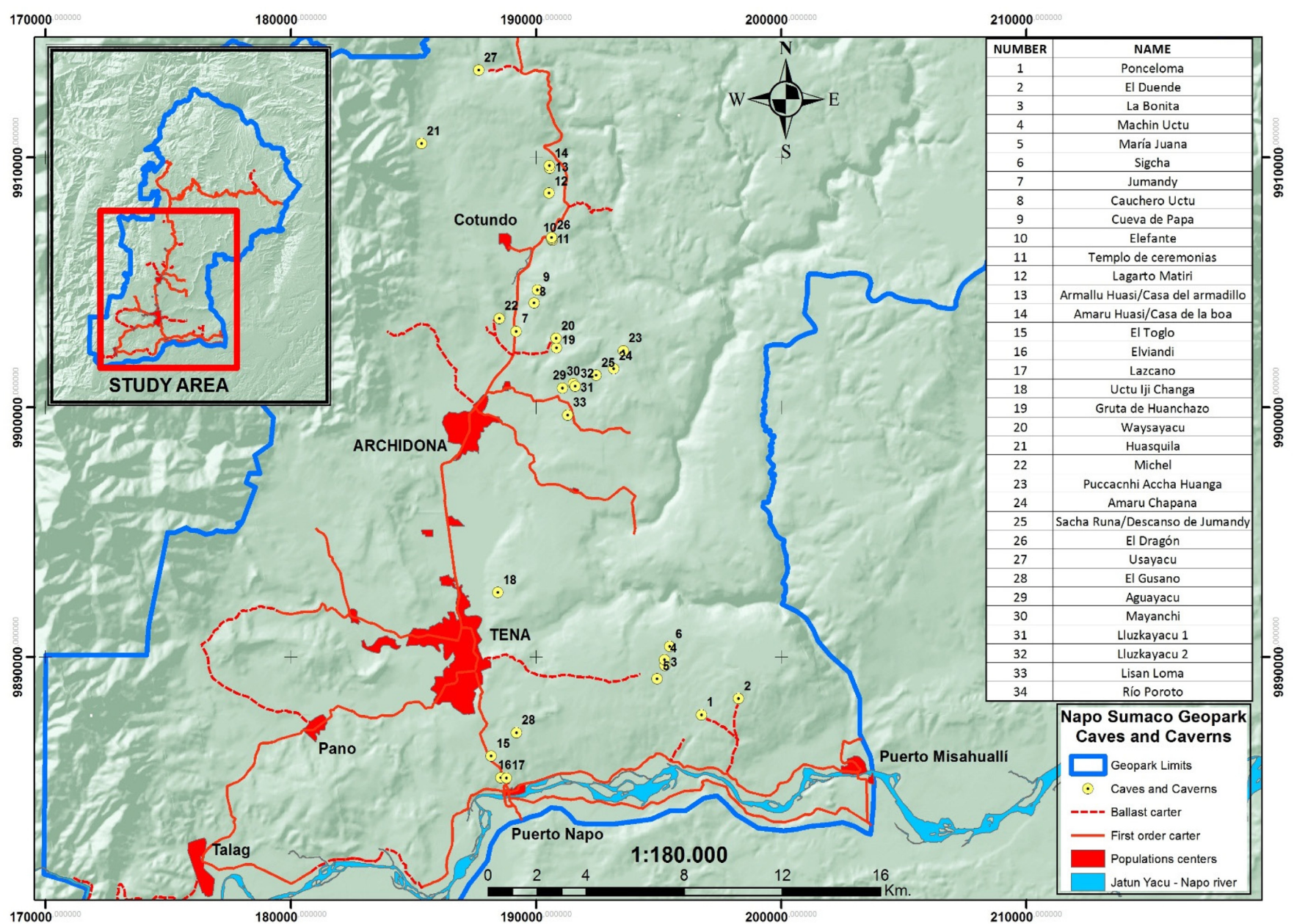

Figure 7. Map of the locations of natural cavities in the province of Napo, within the context of the territory of the Napo Sumaco Geopark. 
rences; between 21 and 40 low occurrences; and between 20 and less than 20 , very low occurrences.

These processes were then applied to raise awareness concerning the need to improve caving practices, and also to establish a list of parameters to improve the current practices.

From these processes, was drawn up a roadmap of the procedures carried out by the guides. After processing qualitative information, a series of main tensors and behaviors that were assigned a range of risk to the safety and management of the geosite. Once the main tensors and inadequate behaviors has been defined, strategies were developed to be implemented in the territory of the Napo Sumaco Geopark. The planning involved a series of activities that were established as elements and processes, in order to standardize and improve the technical procedures for safety guidance and inadequate conduct of the guides and owners of the caves in a framework focused on geoconservation. These strategies employed by the Napo Sumaco Geopark are primarily directed towards the management and geoconservation of the karst cavities, based on the principles of Brilha (2005), and focused on research, socialization and training.

\section{Results}

\section{Identification of Tensors and Pressures in Caves}

For completing field observations, were established routines of work for cave owners and local guides. A checklist was prepared, and tensor assessments were generated, based on current best practices and a hierarchical analysis of driving forces. The evaluation or hierarchy of each force is given by the percentage recurrences of observations of each parameter in the field. The parameters have been developed from observations made exclusively in situ. Each parameter is a force that exerts pressure on the system and allowing or preventing the effective functioning of speleotourism in the geopark. As such, it is preferable to identify mechanisms that reduce these forces (Fischer, 2000).

\section{Targeting strategies}

Although these inventoried cavities have been reported as having some degree of potential to develop geotouristic activities, it is necessary to implement several improvements in the management of these tourist resources (Sanchez-Cortez et al., 2017). Based on the assessments of this quasi-quantitative analysis, recurring parameters are defined in $100 \%$ of caverns inventoried, and have been defined as parameters with very high and high occurrences. Based on these results, problems are prioritized and remedial strategies are proposed. Three types of strategies were proposed: investment, training and research (Table 1). However, in this paper only training and research strategies are presented, due the cavities are either community-owned or private, the investments will have to be made at the expense of the owners.

\section{Training strategies}

Based on the inventory of caves conducted between 2015 and 2017, by Sanchez-Cortez et al. (2017), the geotouristic potential of the caves was determined. This analysis considered three aspects of

Table 1. Analysis of parameters and poor practices by cavity owners during field visits. Observations were made to understand and address training needs of local guides

\begin{tabular}{|c|c|c|c|c|c|}
\hline Number & $\begin{array}{l}\text { Risks in Cave Exploration } \\
\text { for Tourism Purposes }\end{array}$ & Observations & Value & Qualitative Assessment & Mitigation \\
\hline 1 & $\begin{array}{l}\text { Entering caves without security, } \\
\text { improper equipment }\end{array}$ & $\begin{array}{l}\text { Mainly not wearing helmets. Use of safety ropes. } \\
\text { Ensuring the safety of the tourist and guides }\end{array}$ & $100 \%$ & Very High Occurrence & Investment \\
\hline 2 & $\begin{array}{l}\text { Lack of technical information } \\
\text { regarding the caves }\end{array}$ & $\begin{array}{l}\text { Cave maps, cave fauna guides, environmental } \\
\text { physical chemical data }\end{array}$ & $85 \%$ & Very High Occurrence & $\begin{array}{l}\text { Training } \\
\text { Research }\end{array}$ \\
\hline 3 & No use of hand-free flashlights & $\begin{array}{l}\text { Allows free use of hands to assist tourists or use } \\
\text { them for other purposes }\end{array}$ & $80 \%$ & High Occurrence & Investment \\
\hline 4 & $\begin{array}{l}\text { Guides not certified and with little } \\
\text { experience in Group Management }\end{array}$ & $\begin{array}{l}\text { Guiding without proper certification by the compe- } \\
\text { tent authority. The guide must accompany the tour- } \\
\text { ist at the visitors own pace. The guide must not set } \\
\text { the pace. Explain the route and indicate points of } \\
\text { interest; generate variants if the visitor requests it. }\end{array}$ & $75 \%$ & High Occurrence & Training \\
\hline 5 & $\begin{array}{l}\text { Sudden movements; risky and } \\
\text { unsafe actions }\end{array}$ & $\begin{array}{l}\text { During the tour they jump over slippery surfaces, } \\
\text { juggle walks inside the caverns, run and perform } \\
\text { sudden movements }\end{array}$ & $65 \%$ & High Occurrence & Training \\
\hline 6 & $\begin{array}{l}\text { Guides need to include more geolog- } \\
\text { ical and / or scientific information } \\
\text { that complements the cultural } \\
\text { information, as part of their tour. }\end{array}$ & $\begin{array}{l}\text { More information on the formation of the caves } \\
\text { and the ecological dynamics that they generate. }\end{array}$ & $60 \%$ & Average Occurrence & Training \\
\hline 7 & $\begin{array}{l}\text { Emergency plans in the event of } \\
\text { accidents and/or river floods (in the } \\
\text { case of live caverns) }\end{array}$ & $\begin{array}{l}\text { Have a plan in case of emergencies, such as: } \\
\text { panic attacks or phobias, falling blocks by } \\
\text { landslides, flooding of underground channels, } \\
\text { accidents by exploration, among others }\end{array}$ & $50 \%$ & Average Occurrence & Training \\
\hline 8 & $\begin{array}{l}\text { Actions that jeopardize the integrity } \\
\text { of the geological heritage of the } \\
\text { caves }\end{array}$ & $\begin{array}{l}\text { Handling of speleothems and other geological } \\
\text { elements. Entry of large groups. }\end{array}$ & $50 \%$ & Average Occurrence & Training \\
\hline 9 & $\begin{array}{l}\text { It stresses the fauna that inhabits the } \\
\text { caves }\end{array}$ & $\begin{array}{l}\text { Disturb species by trying to touch them or } \\
\text { affecting them with the light of lanterns }\end{array}$ & $40 \%$ & Low Occurrence & Training \\
\hline
\end{tabular}



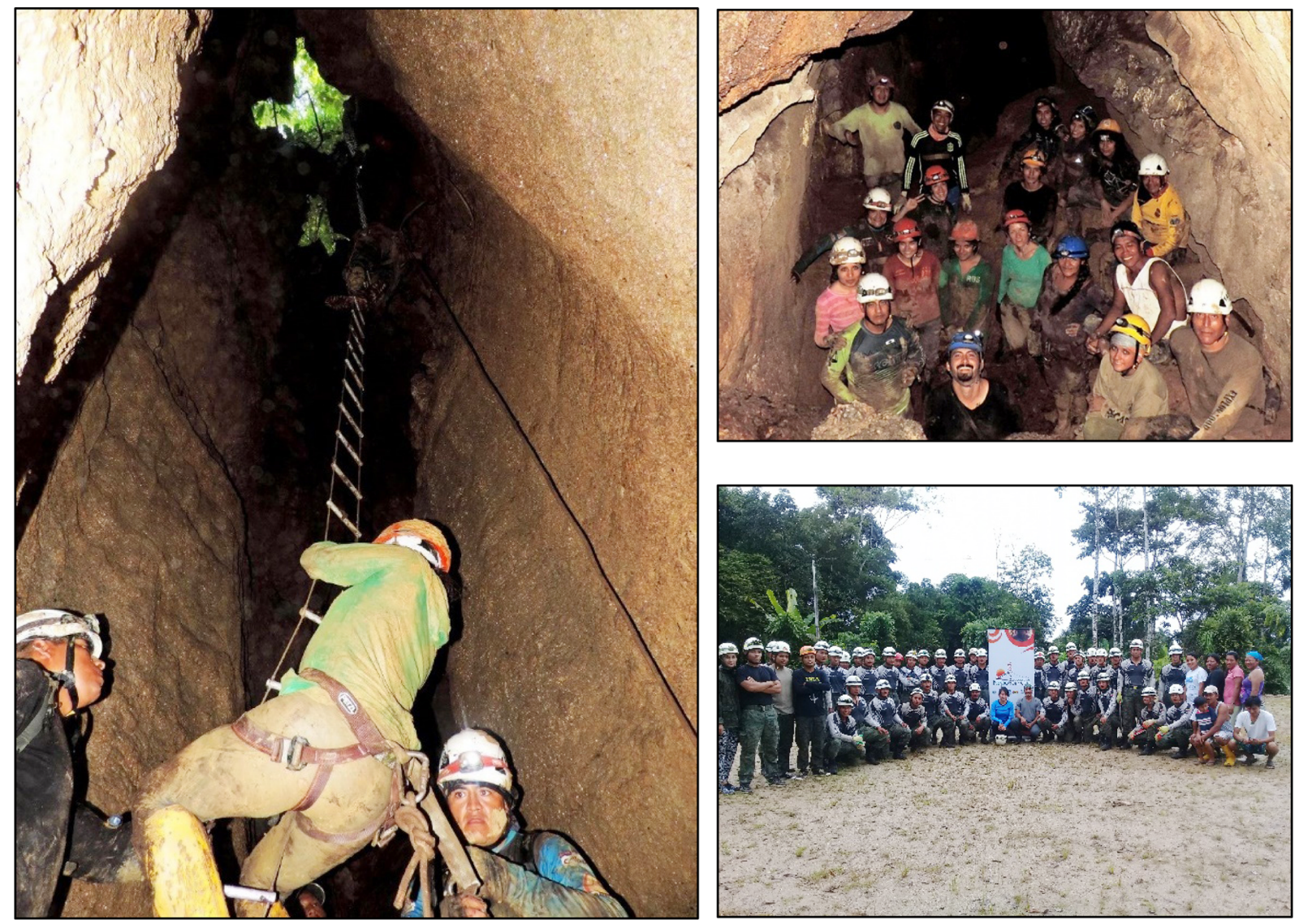

Figure 8 (left). Instruction of exploration maneuvers, use of hanging ladders in the cave of El Duende, during the workshop of techniques for controlled ascents and descents for the exploration of caves, taught for members of the Kichwa communities. Figure 9 (top right). Field trip to the El Duende cave, during the cave Geology workshop in the province of Napo, and as part of the data collection process in situ, several field trips were made with the participation of members of the Kichwa communities. Figure 10 (lower right). Within the collaboration processes of the Napo Sumaco Geopark between institutions, communities and universities, was developed the Cartography and conservation of caverns workshop aimed at Iwias soldiers of the National Army of Ecuador, held in the kichwa community of Tamia Yura, April 2017.

assessment: degree of difficulty, vulnerability and geotouristic potential. Once the caves with the greatest geotouristic potential were identified, some training strategies proposed to strengthen these areas.

In this sense, actions were coordinated with key actors of the territory, both community and local governments (participation of the pro- vincial government of Napo and the municipal governments of Tena and Archidona), the Ministry of Tourism, and the academic support of the Amazonian Regional University Ikiam and the University of Guayaquil; we also had the technical advice of the Group of Explorers "Tayuwas" of the School of "Iwias" of the National Army of Ecua-

Table 2. The topics of the workshops based on the observations made in the field.

\begin{tabular}{|c|c|c|c|}
\hline Workshop & Participants & Organization & Workshop venue \\
\hline $\begin{array}{l}\text { Geology of caves in the } \\
\text { province of Napo: Genesis } \\
\text { and dynamics }\end{array}$ & $\begin{array}{l}\text { Communities and cave owners, students } \\
\text { from Ikiam University (who worked on the } \\
\text { cave inventory) and tourism technicians } \\
\text { from Napo provincial government. }\end{array}$ & $\begin{array}{l}\text { Amazonian Regional University Ikiam, with the } \\
\text { endorsement of the Decentralized Autonomous } \\
\text { Government of Napo and the School of Iwias of } \\
\text { the National Army of Ecuador. }\end{array}$ & Tena \\
\hline $\begin{array}{l}\text { Techniques for controlled } \\
\text { ascents and descents for } \\
\text { cave exploration. }\end{array}$ & $\begin{array}{l}\text { Local guides, cave owners, Ikiam students, } \\
\text { prefecture staff. }\end{array}$ & $\begin{array}{l}\text { Amazonian Regional University Ikiam, with the } \\
\text { endorsement of the Decentralized Autonomous } \\
\text { Government of Napo and the School of Iwias of } \\
\text { the National Army of Ecuador. }\end{array}$ & $\begin{array}{l}\text { Tena and cavities of } \\
\text { Misahualli Parish. }\end{array}$ \\
\hline $\begin{array}{l}\text { Training course for nature } \\
\text { guides in the province of } \\
\text { Napo }\end{array}$ & $\begin{array}{l}\text { Local guides, for the renewal of nature } \\
\text { guide permit. }\end{array}$ & $\begin{array}{l}\text { Municipality of Tena, School of Iwias of the } \\
\text { Ecuadorian Army. }\end{array}$ & $\begin{array}{l}\text { Tena and cavities in } \\
\text { the municipality of } \\
\text { Tena and Archidona. }\end{array}$ \\
\hline $\begin{array}{l}\text { Karst systems: Geology } \\
\text { and biology of the Jumandy } \\
\text { caves }\end{array}$ & $\begin{array}{l}\text { Local Guides of the Ruku Jumandy Kaw- } \\
\text { say community, students and teachers of } \\
\text { the Amazonian Regional University Ikiam }\end{array}$ & $\begin{array}{l}\text { Amazonian Regional University Ikiam } \\
\text { Napo Sumaco Geopark Foundation }\end{array}$ & $\begin{array}{l}\text { Archidona, Jumandy } \\
\text { Caves, Earth Sciences } \\
\text { teaching laboratory in } \\
\text { the Amazonian Regional } \\
\text { University Ikiam }\end{array}$ \\
\hline
\end{tabular}


dor (Figs. 8 to 10). This allowed the formation of a team trained in the exploration and characterization of the underground cavities present in the geopark area.

During the inventory process, in addition to identifying parameters or tensors, information was collected on the main training interests of communities and cavity owners. Workshops were prepared and carried out on the themes set out in Table 2. These workshops were by invitation only and with limited quotas due to the logistics and available equipment. A total of 202 people received theoretical and practical training.

\section{Dissemination strategies}

With the inventory of cavities, a database of caves was established. This information was used for the development of a field manual and concerns the characteristics of the natural cavities present in this territory. The publication of this document was a joint effort between aca- demics and local governments. In short, the Napo Province Speleological Guide was the final product of the Geotourism Inventory of Natural Cavities in the Napo Province project, which covers 35 cavities inventoried during the project, and also includes a general description of each cavity, its location and a range of useful data (Fig. 11). In addition, with the participation of local actors and cavity owners, several of the cavities were mapped using GPS and underground cartographic mapping. This allowed for the development of location maps and internal maps of caves (Figs. 11 to 14).

The purpose of the Speleological Guide of the Province of Napo is to provide to local communities and cave owners with a working tool with compact and true information about the caves present in the territory of the province and the Napo Sumaco Geopark (Sanchez-Cortez, 2017). During the process of carrying out fieldwork, efforts were made to ensure that the objectives of the study were communicated clearly and transparently to the landowners and affected parties. It is understood that much of the ancestral knowledge and knowledge of Amazonian
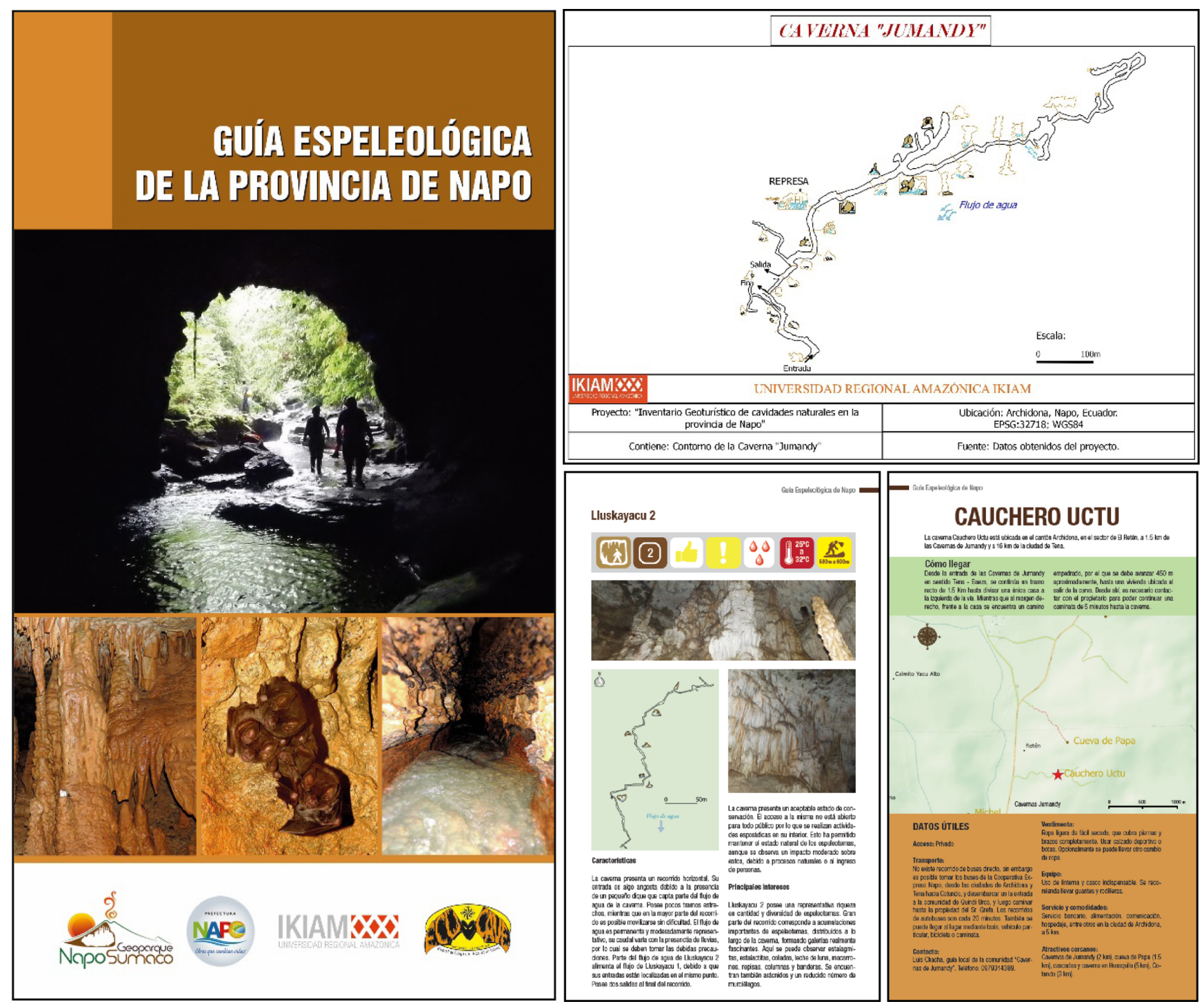

Figure 11 (left). Cover of the Speleological Guide of Napo created as part of the inventory of natural cavities of the Province of Napo. Figure 12 (top right). Map of the interior of the Jumandy caves, prepared by members of Ruku Jumandy Kawsay Community, this map is part of the cavity inventory project. Figures 13 and 14 (lower right). Model of the inside pages of the Speleological Guide of the Province of Napo, showing the symbology used and the location maps of each cavity. 
indigenous peoples has been appropriated without consent and recompense (Andreine, 2013). In this ambit, was agreed that any discoveries would be of a public nature. In addition, the inventory included in the research processes and the subsequent benefits at the inhabitants of the communities.

This manual was conceived as a tool for the dissemination of the geological heritage of Napo, enabling visitors to appreciate and understand the dynamics of the karst relief present more profoundly. The guide also describes how the local world view relates to these geological elements, a fundamental area for the Napo Sumaco Geopark.

\section{Discussion}

Several authors agree that any strategy of geoconservation, must begin with an inventory and documentation of sites of geological interest (Brilha, 2016; Gordon et al., 2018; Gordon, 2019; Ríos et al., 2021), as has been done in the Napo Sumaco Geopark. The process was largely academic, it was carried out with the intent to improve the living conditions of people of the territory (Sanchez-Cortez, 2011). The strategies carried out in this territory are aimed at promoting the development of geotourism and the geoconservation of the geological heritage of the province of Napo.

Geoconservation is a process that involves the dissemination of geological knowledge as the communities in the region are not yet aware of issues related to geological heritage (Brilha, 2005), and include conservation of geodiversity or the application of principles for demonstrate its value (Gordon et al., 2021), for that porpoise the Speleological Guide of the Province of Napo was published. The guide was written with the aim of being accessible to the general public, allowing readers of all levels of education to understand the dynamics of the formation of caves of karst origin.

As part of the geological heritage of the province of Napo, the caves must be included in conservation activities. It should be remembered that the karst cavities are susceptible to human activities (Rincón García and Zafra Otero, 2018). Educative processes are needed, due historically, tourism in the absence of control or training, has been largely responsible for the loss and degradation of speleothems and the fauna associated with these cavities.

Concerning tourism in caves, Cigna and Burry (2000) (in an analysis carried out in about 200 caves in 28 countries with different numbers of visitors), presented data on the local economic impact of cave tourism. The data from the study indicates that, if an average number of visits to the show caves is compiled, assuming an approximate number of 800 tourist caves on the planet, the number of visitors can reach 25 to 150 million annually. In addition, considering that each visitor can spend, in the communities, an average of $\$ 15$ per visit (including food, snacks, transportation, souvenirs), this means an income approximately $\$ 2.3$ trillion per year (Cigna and Burry, 2000). This analysis gives a peripheral view of the importance of the development of speleotourism worldwide. Despite the potential, it is evident there is a lack of knowledge among the tourism authorities concerning speleotourism.

The lack of control and monitoring over the integrity of the caves by the authorities in the past, has resulted in irreparable damage to the heritage, since many of these caves are not part of a nature reserve or conservation areas. In fact, it should be noted that Ecuador does not have any laws that regulating the use of such karst structures (SanchezCortez, 2019). It is necessary to encourage research in the cavities of the region, due is very poor knowledge about this (Sanchez-Cortez and Ortega, 2015). In absence of policies and structures for the conservation of caves, geoparks appear as a territorial strategy that seeks to complement a participatory development system, through mechanisms that promote the conservation of geological elements and the use of them, through productive activities low impact (Lee and Jayakumar, 2021).

The focus of this work has been to provide to each of the communities associated with the caves of the province and its inhabitants, the necessary knowledge to recognize the importance of the geological heritage, and thus encourage and promote its geoconservation, through participatory citizen science mechanisms. This has been achieved through training workshops given through the Napo province's natural cavities inventory project and through outreach activities by the Napo Sumaco Geopark team in the various areas. The perceptions of the communities in the management of their resources must be considered vital in the decision-making process, taking into account the worldview, their knowledge and relationship with the territory, being key pieces in the conservation of the outstanding elements (Koki, 2021).

The desire for research and training has led to the creation of a sustainable geotourism system through the Napo Sumaco Geopark, which allows communities to take advantage of geological attractions, improve the economy and in doing so, improve their quality of life. In addition, it is hoped that the communities in the territory will contribute to the geoconservation of speleological heritage (Vasquez, 2015). However, is necessary for authorities and institutions, to be linked to such initiatives and to promote programs focused on the conservation of the geological heritage not only of Napo, but in all country (SanchezCortez et al., 2017).

As a result of this work, were possible the interactions between academy, local authorities and guides, through training and dissemination strategies in the geopark territory; Napo Sumaco Geopark has been started a process of geotourism sustained by the Kichwa communities of Napo, with local guides or community tourism centers, called Pushak Runa. This guides groups have become essential to develop a cavern and geosite management scheme that considers the safety of tourists and local knowledge.

\section{Conclusions}

Karst cavities form one of the geosites in Napo Sumaco Geopark (Subterranean karstic relief) and represent an important geological, biological, cultural and strategic factor. The caves combining scientific and traditional knowledge, which is important to understand different dynamics and needs of the territory. Furthermore, the caves are positioning as local sources of socio-economic development.

Although the use of geotourism activities is widely developing within the geopark, and speleotourism is a fairly common practice in the territory. The present work shows various deficiencies related to intrinsic geological knowledge and the perception of risks. This research shows that citizen science always requires academic support to improve the 
processes established within the territory. Geoparks base their structures on social participation, however there must be a correct direction based on the deficits diagnosed in the territory.

The present research framed and established the needs of the territory, and based on them, the ways to solve these needs are planned in a timely manner, through dissemination and training strategies. This work approach creates the opportunity to carry out future evaluations, to define the degree of effectiveness that has been achieved with the application of the proposed strategies. Finally, these strategies outline the action plan and master plan of the geopark, based on the requirements generated from the communities.

\section{Acknowledgements}

JLSC, DJB, MST, DAB, ECC, Napo Sumaco Geopark extends its thanks to the Kichwa communities located within the geopark territory and to the owners of caves and caves studied, the provincial Decentralized Autonomous Government of Napo for their support in the development of this project. Thanks to Amazonian Regional University Ikiam, University of Guayaquil, Group of explorers "Tayuwas" of the School of Iwias of the National Army of Ecuador, and the Municipal decentralized autonomous governments of Tena and Archidona.

\section{References}

Andreine, S., 2013, La protección y control de los conocimientos tradicionales y la propuesta de un régimen sui generis el Ecuador como caso de estudio. http://repositorio.usfq.edu.ec/handle/23000/2936 [accessed 20th June 2020].

Andy, P., Calapucha, C., Calapucha, L., López, H., Shiguango, K., Tanguila, A., Tanguila, D., and Yasacama, C., 2012, Sabiduría de la Cultura Kichwa de la Amazonía Ecuatoriana Tomo II. Tena- Napo, Ecuador.

Arias, R.I., Tapia, A., Tapia, A., Santacruz, L., Yasaca, R., and Miranda, N., 2012, Evaluación de la biodiversidad en cinco comunidades Kichwa de la zona de colonización de la alta Amazonía ecuatoriana. Revista Amazónica: Ciencia y Tecnología, v. 1, pp. 157-172.

Arias-Gutiérrez, R.I., Herrera Sorzano, A., and González Sousa, R., 2016, Poblamiento indígena amazónico y desarrollo local en Pastaza, Ecuador. Novedades en población. Año XII, No.23, january-june, pp. 24 34.

Baby, P., Rivadeneira, M., and Barragán, R., 2014, La cuenca oriente: geología y petróleo. Convenio Ifea-ird-petroamazonas Ep, Quito, $414 \mathrm{p}$.

Baldock, J.W., 1982, Geología del Ecuador, Boletín de Explicación del Mapa Geológico del Ecuador a 1:1'000.000. Ministerio de Recursos Naturales y Energéticos, Dirección General de Geología y minas, Quito, $80 \mathrm{p}$.

Balseca, W., Ferrari, L., Pasquare, G., and Tibaldi, A., 1993, Structural evolution of the northern Sub-Andes of Ecuador: The Napo Uplift. Second ISAG, 1993. Oxford, United Kingdom, p. 21-23.

Barragán, R., and Baby, P, 2004, Evolución magmática actual de la zona Sub-Andina: volcanes El Reventador y Sumaco, modelos geodinámicos preliminares. In: Baby, P., Rivadeneira, M., Barragán, R. (Eds.). La Cuenca Oriente: Geología y Petróleo. Quito, Ecuador. pp. 183201.

Brilha, J., 2005, Patrimonio Geológico e Geoconservação: A Conservação da Natureza na sua Vertente Geológica. Palimage Editores, Braga, pp. 190.
Brilha, J., 2016, Inventory and quantitative assessment of geosites and geodiversity sites: A review. Geoheritage, v. 8, pp. 119-134.

Cigna, A.A., and Burri, E., 2000, Development, management and economy of show caves. International Journal of Speleology, v. 29, pp. 1-27.

Constantin, S., Toulkeridis, T., Moldovan, O.T., Villacís, M., and Addison, A., 2018, Caves and karst of Ecuador - state-of-the-art and research perspectives. Physical Geography, 40:1, pp. 28-51.

Descola, P., 2004, Las Cosmologías Indígenas de la Amazonía. Tierra Adentro. In: Surrallés, A. and García Hierro, P. (Eds.). Territorio Indígena y Percepción del Entorno. Documento No. 39, Copenhague, pp. 25-35.

Farsani, N.T., Coelho, C., and Costa, C., 2010, Geoturism and Geoparks as Novel Strategies for Socio-economic Development in Rural Areas. International Journal of Tourism Research, v. 13, pp. 68-81.

Finer, M., Jenkins, C.N., Pimm, S.L., Keane, B., and Ross. C., 2008, Oil and gas projects in the western amazon: threats to wilderness, biodiversity, and indigenous peoples. PLoS ONE v. 3, e2932. doi:10.1371/journal.pone.0002932

Fischer, D.W., 2000, Técnicas para la formulación de políticas en zonas costeras. Universidad Autónoma de Baja California. Mexicali, Baja California, México, 246 p.

Goldáraz, J.M., 2005, Samay, la herencia del espíritu- Cosmovisión y ética Naporunas. CICAME, Quito. 190 p.

Gordon, J.E., Crofts, R., and Díaz-Martínez, E., 2018, Geoheritage conservation and environmental policies: retrospect and prospect. In: Reynard, E. and Brilha, J. (Eds.), Geoheritage. Assessment, protection, and management, Elsevier, Amsterdam, pp. 213-235.

Gordon, J.E., 2019, Geoconservation principles and protected areas management. International Journal of Geoheritage and Parks, v. 7, pp. 199 210. doi:10.1016/j.ijgeop.2019.12.005

Gordon, J.E., Crofts, R., Gray, M., and Tormey, D., 2021, Including geoconservation in the management of protected and conserved areas matters for all of nature and people International Journal of Geoheritage and Parks, v. 9, pp. 323-334. doi:10.1016/j.ijgeop.2021.05.003

Gray, M., 2011, Other nature: Geodiversity and geosystem services. Environmental Conservation, v. 38, pp. 271-274.

Grefa, D., 2020, Interview with Darwin Grefa, Cultural Researcher.

Koki, J., 2021, The Beliefs of Local Communities towards the Conservation of Birds. Journal of Human, Earth and Future, v. 2, pp. 36-54. doi:10.28991/HEF-2021-02-01-04

Langer, P., 2020, Groundwater Mining in Contemporary Urban Development for European Spa Towns. Journal of Human, Earth and Future, v. 1, pp. 1-9. doi:10.28991/HEF-2020-01-01-01

Lee, Y., and Jayakumar, R., 2021, Economic impact of UNESCO Global Geoparks on local communities: Comparative analysis of three UNESCO Global Geoparks in Asia. International Journal of Geoheritage and Parks, v. 9, pp. 189-198. doi:10.1016/j.ijgeop.2021.02.002

Lino, C.F., 2001, Cavernas: o fascinante Brasil subterrâneo. Second Edition, Lipps, E.F., Remia, Sao Paolo, 288 p.

Manzanilla, L., 1994, Las cuevas en el mundo mesoamericano. Revista Ciencias. Núm. v. 36, pp. 59-66.

Newsome, D., Dowling, R., and Leung, Y., 2012, The nature and management of geotourism: A case study of two establish iconic geotourism destinations. Tourism Management Perspectives, v. 2, pp. 19-27.

Ólafsdóttir, R., and Dowling, R., 2014, Geotourism and Geoparks-A Tool for Geoconservation and Rural Development in Vulnerable Environments: A case study from Iceland. Geoheritage, v. 6, pp. 71-87. doi:10.1007/ s12371-013-0095-3

Ordoñez de Cevallos, P., 1691, Historia y viage del Mundo, del clérigo agradecido, Don Pedro Ordoñez de Cevallos, natural de la insigne ciudad de Jaén, a las cinco partes de la Europa, África, Asia, América y Magalanica, con el itinerario de todo él. En Madrid: por Juan García Infanzón, $432 \mathrm{p}$.

Palacios Villavicencio, M., 2015, WAA: Cosmovisión ancestral de las cuevas. In: Toulkeridis, T., Constantin, S., Addison, A. (Eds.). 3er Simposio 
Internacional de Espeleología en el Ecuador. Boletín Científico, Tena, Ecuador. pp. 18-25.

Palmer, A.N., 2012, Geología de Cuevas. Dayton, EEUU, Cave Books. $502 \mathrm{p}$.

Peters, M.A., and Besley, T., 2019, Citizen science and post-normal science in a post-truth era: Democratising knowledge; socialising responsibility. Educational Philosophy and Theory, v. 51, pp. 12931303. doi:10.1080/00131857.2019.1577036

Ramos Donato, C., 2019, El eco de las cuevas: de la disolución a la vida. Editorial, Appris e Livraria Eireli- ME. 275 p.

Rincón García, J.P., and Zafra Otero, D., 2018, Las Regiones Kársticas, una opción para el Desarrollo Sostenible en Santander, Colombia. Universidad Industrial de Santander, 14 p. doi:10.13140/RG.2.2.19754. 93125

Ríos, C.A., Amorocho, R., Villarreal, C.A., Mantilla, W., Velandia, F.A., Castellanos, O.M., Muñoz, S.I., Atuesta, D.A., Jerez, J.H., Acevedo, O., Vargas, M., Caballero, V.M., Goso, C.A., and Briggs, A., 2020, Chicamocha Canyon Geopark project: A novel strategy for the socioeconomic development of Santander (Colombia) through geoeducation, geotourism and geoconservation. International Journal of Geoheritage and Parks, v. 8, pp. 96-122, doi:10.1016/j.ijgeop.2020.05.002

Sánchez-Cortez, J.L., 2011, Geoparques y Áreas Naturales Protegidas: Una visión desde la conservación, identidad y participación social. Investigación ambiental. Ciencia y política pública, v. 3, pp. 44-51.

Sánchez-Cortez, J.L., and Ortega, L., 2015, Perspectivas para el uso y aprovechamiento de cavidades naturales en la provincia del Napo, a partir de procesos educativos, investigativos y turísticos. In: Toulkeridis, T., Constantin, S., Addison, A. (Eds.). 3er Simposio Internacional de Espeleología en el Ecuador. Boletín Científico. Tena, Ecuador, pp. 88-103.

Sánchez-Cortez, J.L., Cárdenas-Pinto, V., Ocampos-Valarezo, D., JaqueBonilla, D., Quilumba-Dután, D., Ortiz-Barrionuevo, J., QuinterosCevallos, R.A., and Toledo-Rojas, N., 2017, Aplicación de Proceso Metodológico para el Inventario Geoturístico de Cavidades Naturales en la Provincia de Napo - Ecuador. Anuário Do Instituto de Geociências, v. 40, pp. 61-73. doi:10.11137/2017_2_61_73

Sánchez-Cortez, J.L., 2017, Guía Espeleológica de la Provincia de Napo.
Tena, Ecuador. 106 p.

Sánchez-Cortez, J.L., 2019, Conservation of geoheritage in Ecuador: Situation and perspectives. International Journal of Geoheritage and Parks, v. 7, pp. 91-101, doi:10.1016/j.ijgeop.2019.06.002

Taylor, S.J., and Bogdan, R., 1986, Introducción a los métodos cualitativos. La búsqueda de significados. Editorial Paidos, 1era Edición, Barcelona, $343 \mathrm{p}$.

Toulkeridis, T., Zambrano Ballesteros, A., Camilo Tapuy Vargas, B., Castillo, C., Rodriguez, C., Chavez, C., and Carmona Terán, X., 2015, 3er Simposio Internacional de Espeleología en el Ecuador. Boletín Científico. Tena, march 13-15, 2015, 180 p.

Toledo, V. M., and Barrera-Bassols, N., 2008, La Memoria Biocultural. La importancia ecológica de las sabidurías tradicionales. Editorial Icaria. Perspectivas Agroecológicas. Barcelona, España, 232 p.

Trojan, J., Schade, S., Lemmens, R., and Frantál, B., 2019, Citizen science as a new approach in Geography and beyond: Review and reflections. Moravian Geographical Reports, v. 27, pp. 254-264. doi:10.2478/mgr-2019-0020

UNESCO, 2015, Operational guidelines for UNESCO Global Geoparks. http://www.unesco.org/new/fileadmin/MULTIMEDIA/HQ/SC/pdf/ IGGP_UGG_Statutes_Guidelines_EN.pdf [accessed 10th January 2020].

Vásquez Vega, A.M., 2015, Evaluación de la sostenibilidad del espeleoturismo en las cuevas ubicadas dentro de la zona de Cotundo, provincia de Napo. Pontificia Universidad Católica del Ecuador. http:// repositorio. puce.edu.ec:80/xmlui/handle/22000/10298 [accessed 25th January 2020].

Wimbledon, W.A.P., and Smith Meyer, S., (Eds.), 2012, Geoheritage in Europe and its conservation. ProGEO, $405 \mathrm{p}$.

Yuquilema, J., 2010, Modelo depositacional de la arenisca "T" en la cuenca oriente. Escuela Politécnica Nacional, Quito, 198 p.

Zurita Benavides, M.G., 2014. Du "temps du tapir" à nos jours: les marques du temps dans le paysage. Perspectives de deux villages waorani sur les relations entre les espaces forestiers et le temps en Amazonie équatorienne. Muséum National d'Histoire Naturelle, Paris. Thèse doctorat. 


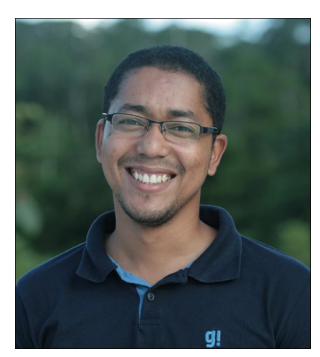

José Luis Sánchez-Cortez, Geologist, $\mathrm{PhD}$. in Environment and Development (2013). Professor Researcher at the University of Guayaquil, Faculty of Natural Sciences. Expert in geological heritage and geoconservation based on community social participation structures. He has participated in workshops and projects on Geological Heritage, Geodiversity, Geoconservation and Geoparks in Latin America, Europe and Asia. Manager and Scientific Coordinator of the Napo Sumaco UNESCO Aspiring Geopark.

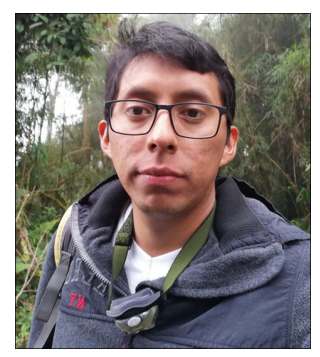

Daniel Jaque-Bonilla, student of the Geoscience Engineering Career at Ikiam Amazonian University. Member of the Napo Sumaco Geopark Foundation, and leader of the caves and karst group of the Napo Sumaco Geopark volunteer corps. Principal Investigator in the Project Geotouristic inventory of natural cavities in the province of Napo (Ecuador): Documentation of orality and related strategic resources. Participated as Speaker in the First Colombian Speleological Congress.

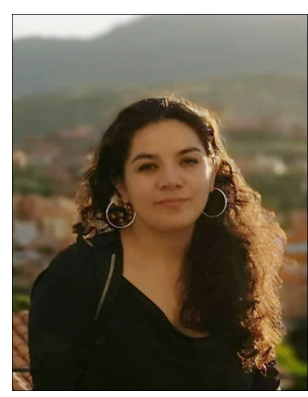

Diana Astudillo-Bravo, Social Communicator, Master in Social Sciences with a major in Communication (2012). Professor Researcher at Ikiam Amazonian University. She has developed issues related to territorial identity, culture and heritage in the territory of the Napo Sumaco Geopark. Academic promoter of the cultural project "Ahuano Warmis".

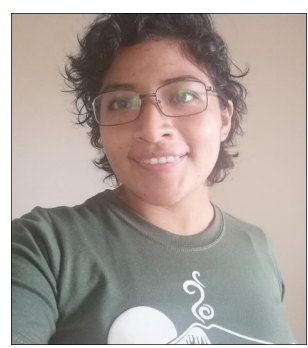

Estefanía Cabascango-Chiliquinga, student of the Geoscience Engineering Career at Ikiam Amazonian University. Leader of the volunteer corps of the Napo Sumaco Geopark. Coordinator of actions and activities in Napo Sumaco territory, it is also the link with organizations and links with local communities.

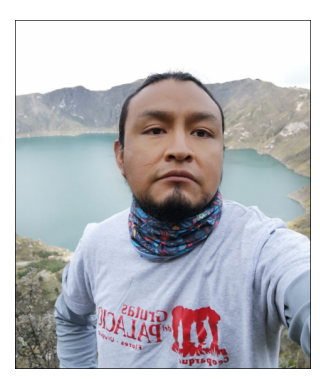

Marco Simbaña-Tasiguano, Geology Engineer, Master in Environmental Geology and Geological Resources (2015). Professor Researcher at Ikiam Amazonian University, Geoscience Engineering Career. General Coordinator and Director of the Napo Sumaco Geopark Foundation, currently leading the Napo Sumaco application process to UNESCO. 